\title{
Erratum to: First mover advantages and optimal patent protection
}

\section{F. M. Scherer ${ }^{1}$}

\section{Erratum to: J Technol Transf DOI 10.1007/s10961-015-9394-y}

The original version of this article contained an error in the vertical scale of Figure 4. The price marked " 35 " should be " 25 ." The error is also transported into the text on page 7 (8th line). The error does not invade the calculations underlying Tables 1 and 2 or other tables presented in a longer version of the paper.

The online version of the original article can be found under doi:10.1007/s10961-015-9394-y.

$\triangle$ F. M. Scherer

mike_scherer@hks.harvard.edu

1 John F. Kennedy School of Government, Harvard University, Cambridge, MA 02138, USA 